\title{
Effect of T\&V innovation on income and farmers performance in Edo State Nigeria
}

\author{
Abiola Matthew Oladipupo ${ }^{1}$, Omoregbee Friday Egbenayabuwa ${ }^{2}$, Caroline Sede ${ }^{2}$ \\ ${ }^{1}$ Department of Agricultural Economics and Extension, Faculty of Agriculture, Federal University of Oye Ekiti State, Nigeria \\ ${ }^{2}$ Department of Agricultural Economics and Extension Services, University of Benin, Edo State, Nigeria \\ Email address: \\ maidenjournal@yahoo.com(A. M. Oladipupo),fridayomoregbee@yahoo.com (O. F. Egbenayabuwa )
}

\section{To cite this article:}

Abiola Matthew Oladipupo, Omoregbee Friday Egbenayabuwa, Caroline Sede. Effect of T\&V Innovation on Income and Farmers Performance in Edo State Nigeria. American Journal of Agriculture and Forestry. Vol. 2, No. 4, 2014, pp. 159-167.

doi: 10.11648/j.ajaf.20140204.19

\begin{abstract}
The study examined the effect of training and visit innovation on the income and famer performance in two out of three agro ecological zones of Edo State, Nigeria. This study focused on contact crop farmers drawn from two out of three agro-ecological zones of Edo State, namely Edo central and Edo south. A multi-stage random sampling method was used both for economic reasons and especially because the sampling units occur in strata such as zones, blocks and cells. Data were collected from randomly sampled respondents from two senatorial districts in Edo State. Edo state is divided into three agro-ecological zones- Edo North, Edo Central and Edo South, out of which Edo Central and Edo south were randomly selected. Two blocks each were selected randomly from a total of five and seven blocks in Edo central and Edo south zones respectively. These blocks were Igueben and Esan North East in Edo central and Oredo and Egor in Edo south senatorial zone. Each block consists of eight cells. A random selection of four cells was made from each block and total of sixteen cells were chosen and eight from each zone and ten farmers were randomly selected from each of the 16 cells, giving a total of one hundred and sixty farmers/respondents for the study but only a hundred and fifty six copies of a questionnaire were found useful for the study. Data collected were subjected to descriptive statistics and budgetary tools. The outcome of the study indicated that training and visit innovation had increasing effect on farm size and income of farmers in the study areas.
\end{abstract}

Keywords: Income, Training, Visits, Innovation, Edo

\section{Introduction}

\subsection{The T\&V Extension System and Agricultural Food Production}

Daniel Benor's Training and Visit (T\&V) extension system was vigorously introduced to Nigeria in 1986 by the World Bank and was subsequently adopted in all the 36 states and the federal capital territory. It is regarded as a potent weapon for heralding a true agrarian revolution. (Ilevbaoje, 2004).Agricultural extension system is the primary delivery system for information to farmers (Munyua et al. 2002). Improving agricultural productivity may not be achieved without relevant and reliable agricultural information. The objective of any extension system is to be effective in communicating information that helps people in decision-making. The T\&V extension system modified to suit each country's agricultural goals is a dominant extension approach used in reaching farmers with information on agricultural production.

Agricultural extension has the potential to stimulate agricultural development and is often used as a tool for implementing government policy. It is recognized as the main link between the farmers and research and crucial in communicating improved practices needed in agricultural development (Rivera and Carey, 1997 and Van den Ban and Hawkins, 1996). As indicated by the World Bank (1997), supply of appropriate technology is essential if extension investments are to be worthwhile and especially for public sector extension.

According to Sappho (1993) research and extension should be closely linked in order to contribute appreciable and sustainable increase in food production. The goal of agricultural extension is to facilitate farmers' acceptance of innovative practices from research which should lead to increased output, productivity and incomes. This agrees 
with FAO (1997) which states that improved agricultural extension management system is recognized as a central mechanism to achieving increased food productivity through technology transfer. The $\mathrm{T} \& \mathrm{~V}$ is one of the foreign innovations introduced to improve famer's performance in Nigeria. What is the effect of this innovation on famer's income and performance? .The specific objectives of the study include:

A To examine the socio-economic characteristics of famers in Edo State

B Determine the effect of T\&V innovation on farmer's income.

$\mathrm{C}$ Identified the perceived benefits derived by famers from $T \& V$ innovation in Edo State, Nigeria

Nigeria is one of the 60 countries now using the T\&V extension system. Like many developing countries, Nigeria adopted the $\mathrm{T} \& \mathrm{~V}$ extension system in 1986 because of its promise of improving extension management which is the key to increased agricultural production and national development. It was formally introduced through pilot testing in Oyo, Kaduna, Imo and Plateau states. Guided by experience from the pilot ADPs, implementation assistance terms (IATs) were mounted by Federal Agricultural Coordination Unit (now Project Coordination Unit (PCU)) to rapidly and systematically replicate the $\mathrm{T} \& \mathrm{~V}$ extension model in all the state ADPs (Ilevbaoje, 2004). There is a general consensus that farm level utilization of agricultural research institutes' results (developed technologies) has not made the expected impact on agricultural production in Nigeria. Research Institutes' results differ markedly from actual farm yields indicative of development-adoptive (use) gap. For instance, in the Nigerian Institute for Oil palm Research (NIFOR), the yield per hectare on experimental plots range from 15 to 18 tonnes per annum, while yield on farmers' field is 8-10 tonnes per annum (Omokhudu, 1998). The difference between experimental station yield, the potential farm yields and the actual farm yields has been attributed to biological and socio-economic constraints as well as the communication channels through which these technologies get to the (end users) farmers (Akinbode, 1976).

Many valuable results have been obtained from most of the agricultural research institutes, but these agricultural practices do not get to the farmers.

This situation has created a wide gap between research and the utilization of the research results. To enable effective service, the ideal ratio of extension agent to farm family should be 1:250 (Benor and Baxter, 1984).

This clearly suggests that one of the strategies of developing the agricultural sector in Nigeria is to ensure that these developed technologies get to the farmers through the Training and Visit system. But unfortunately, because the farmers are scattered and isolated, extension agents are very few to be able to carry out this effectively by individual contact, a communication channel that has be regarded to be the most effective in disseminating technologies to the target audience (Laogun 1985).
Table 2.1 below shows the extension agent/ farm family ratio as at the year 2000 in 27 States in Nigeria. Majority $(96 \%)$ of the states have more than 1000 farm families to one extension agent. The state with the highest ratio is Lagos with 1:5800, while the state with the least ratio is Gombe with 1:826. None of the 27 states achieved the recommended extension agent $\mid$ farm family ratio of 1:250.

Table 1. Extension agent/farm family ratio in Agricultural Development Programmes in 27 states in Nigeria

\begin{tabular}{|c|c|c|}
\hline $\mathbf{S} / \mathbf{N}$ & State ADP & $\begin{array}{l}\text { Extension Agent- Farm Family } \\
\text { Ratio }\end{array}$ \\
\hline 1 & Abia & $1: 1000$ \\
\hline 2 & Adamawa & $1: 1452$ \\
\hline 3 & Akwa-IBOM & $1: 2320$ \\
\hline 4 & Anambra & $1: 3084$ \\
\hline 5 & Bauchi & $1: 1238$ \\
\hline 6 & Bayelsa & $1: 2893$ \\
\hline 7 & Benue & $1: 1460$ \\
\hline 8 & Borno & $1: 1268$ \\
\hline 9 & Ebonyi & $1: 5320$ \\
\hline 10 & Edo & $1: 1500$ \\
\hline 11 & Ekiti & $1: 2800$ \\
\hline 12 & Enugu & $1: 4041$ \\
\hline 13 & Gombe & $1: 826$ \\
\hline 14 & Imo & $1: 2861$ \\
\hline 15 & Jigawa & $1: 1075$ \\
\hline 16 & Kaduna & $1: 3500$ \\
\hline 17 & Kano & $1: 2267$ \\
\hline 18 & Katsina & $1: 1750$ \\
\hline 19 & Kebbi & $1: 1000$ \\
\hline 20 & Kwara & $1: 1000$ \\
\hline 21 & Lagos & $1: 5800$ \\
\hline 22 & Nasarawa & 1:1381 \\
\hline 23 & Niger & $1: 5000$ \\
\hline 24 & Ogun & $1: 1857$ \\
\hline 25 & Ondo & 1:1900 \\
\hline 26 & Taraba & $1: 1065$ \\
\hline 27 & Yobe & 1:1120 \\
\hline
\end{tabular}

Source: Project Coordinating Unit, Abuja (2000)

The nation-wide adoption of $\mathrm{T} \& \mathrm{~V}$ extension approach is perhaps the most outstanding development in agricultural extension in Nigeria over the past two decades or so. According to Ilevbaoje (2004), some of the problems which the $\mathrm{T} \& \mathrm{~V}$ extension system attempt to solve are:

- to improve the organization of extension by introducing a singular direct line of technical support and administrative control,

- to change the multi-purpose nature of many extension workers to a clearly defined, singlepurpose role involving only education and communication activities,

- to improve coverage by limiting the number of farm families or households one extension worker is expected to visit

- to improve mobility by providing appropriate transport so that each worker can regularly visit his/her contact farmers 
- to improve each extension worker's technical skill and knowledge about improved agricultural technology by providing in-service training sessions

- to improve extension's ties with agricultural research through an increased number of subject matter specialists, who are expected to maintain regular contact with their research counterparts and to secure a continuous flow of information that transmits technology to farmers and farmers' problems back to research personnel

- to improve the status of extension personnel by giving them a relatively clear-cut extension job with reasonable expectations that they can successfully carry out; this will increase their level of respect in the community and begin to build their self-confidence, and

- $\quad$ to reduce the duplication of services that occurs when extension is fragmented among different ministries.

The T\&V System of Extension management has been adopted in several developing countries to revitalize their agricultural extension services. Studies of agricultural extension services in these countries reveal various experiences. Ada-Okungbowa and Ojukoko (2003) found significant differences in farm size and income of farmers at both $95 \%$ and $99 \%$ confidence limit of adopters of improved cassava varieties in Delta states as against that of non-adopters.

\section{Methodology}

\subsection{Area of Study}

The study was carried out in Edo State. Edo state has an area of about 19,794 Kilometers and a provisional population of $2,159,848$. It lies roughly between longitude 050 04' $\mathrm{E}$ and 060 43'E and latitudes $05044^{\prime} \mathrm{N}$ and 070 $43^{\prime} \mathrm{N}$. It is bounded on the North by Kogi State, on the West by Ondo State, on the South by Delta State and on the East by Kogi and Anambra States (Iloeje, 2002).

Edo State has a tropical climate characterized by two distinct seasons, the wet and dry seasons. The wet season occurs between April and October with a break in August and an average rainfall ranging from $150 \mathrm{~cm}$ in the extreme north of the state to $250 \mathrm{~cm}$ in the south. The dry season lasts from November to April while a cold harmmattan is between December and January. The temperature averages about $25^{\circ} \mathrm{C}$ in the rainy reason and $28^{\circ} \mathrm{C}$ in the dry season (Iloeje, 2002).

The climate is humid tropical in Edo South agroecological zone which covers the Benin City area. It is mainly characterized by heavy rains almost all year round and thick rain forest. Edo North agro-ecological zone covers the Auchi area of the State which has a sub-humid climate and is characterized by light rainfall and semisavannah vegetation. Edo Central agro-ecological zone covers the Ekpoma area of Edo State which lies between the south and the north.

More than $70 \%$ of the population of Edo State make their living from agriculture. They cultivate cash crops such as rubber (Hevea brasiliensis), oil palm (Elaeis guineensis) and cocoa (Theobroma cacao), food crops such as yam (Dioscorea specie), cashew (Anacardium occidentale),

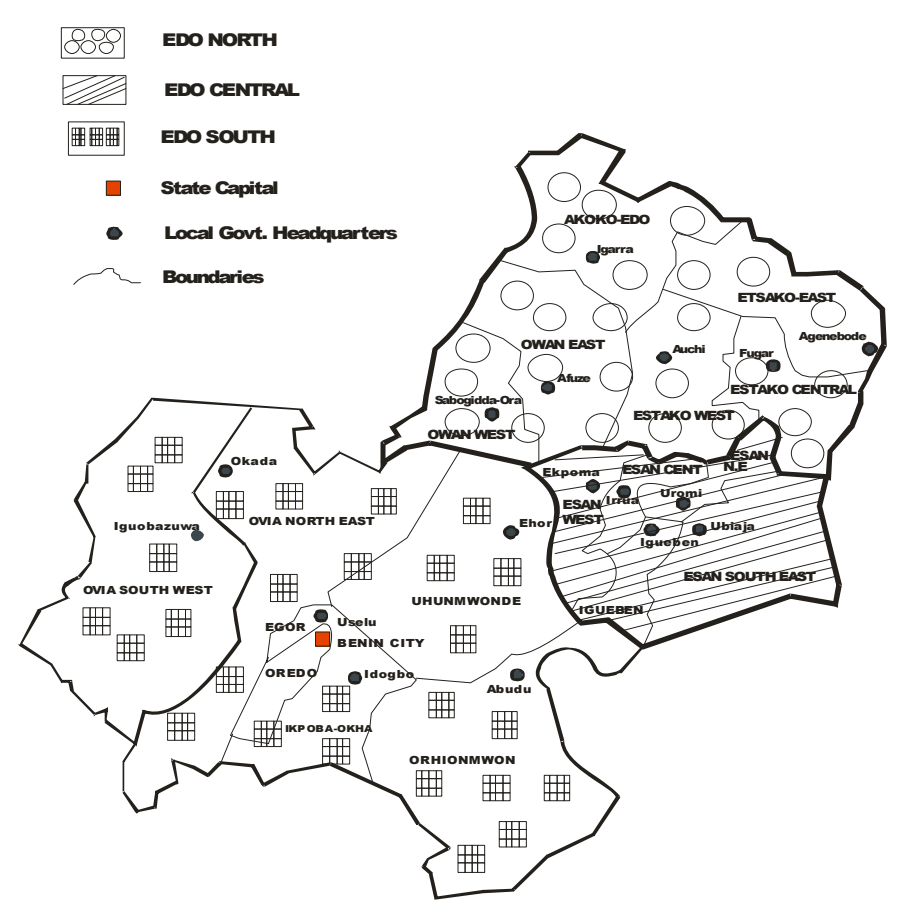

Edo State Map Showing the three Senatorial Districts

Figure 1. Map of Edo State showing the three agro-ecological zones. 
Cassava (Manihot esculenta), rice (Oryza species), plantain (Plantago media), maize (Zea mays), sugar cane (Saccharum officinarum), groundnuts (Arachis hypogea), soya-beans (Glycine max) and coco yams (Xanthosoma sagittifolium). Fruits like pine -apple (Ananas Specie), coconut (Cocos nucifera), Oranges (Citrus species), pawpaw (Carica papaya) and mango (Mangifera indica).

\subsection{Study Population and Sample Size}

This study focused on contact crop farmers drawn from two out of three agro-ecological zones of Edo State, namely Edo central and Edo south. The population of farmers in this area is about $1,007,929$.

A multi-stage random sampling method was used both for economic reasons and especially because the sampling units occur in strata such as zones, blocks and cells. The sampling process proceeded as follows:

Zonal Level- Edo state is divided into three agroecological zones- Edo North, Edo Central and Edo South, out of which Edo Central and Edo south were randomly selected.

Block Level- Two blocks each were selected randomly from a total of 5 and 7 blocks in Edo central and Edo south zones respectively. These blocks were Igueben and Esan North East in Edo central and Oredo and Egor in Edo south senatorial zone.

Cell Level- Each block consists of 8 cells. A random selection of 4 cells was made from each block. A total of 16 cells were thus chosen, with 8 from each zone.

Farmers' level- 10 farmers were randomly selected from each of the 16 cells, giving a total of 160 farmers/respondents for the study. However, only 156 copies of respondents' interview schedule were useful for analysis.

\begin{tabular}{lll}
\hline Zones & Blocks & Cells \\
\hline Edo Central & Igueben & Ekekhen/Idumugo \\
& & Eguare/Oyomon \\
& & Afuda/Idumuka \\
& Uhe/Idumogbo \\
& Esan North East & Uzeha \\
& & Emendokhian \\
& Ivue/Obedu \\
& & Isua/Arue \\
Edo South & Oredo & Ogbe-ebuya \\
& & Iyeko-Ogba \\
& & Uzebu \\
& & Esigie \\
& Egor & Uselu 1 \\
& & Uselu 2 \\
& & Ohoro \\
& & Ugbowo \\
\hline
\end{tabular}

This study made use of both primary and secondary sources to obtain data. An interview schedule was employed in getting primary data. The secondary data were sourced from textbooks, journals, previous articles, State Agricultural Development Programme, the internet and related literature on the topic.
A structured interview schedule was employed in gathering primary information from the respondents. The instrument utilized a combination of close-ended and openended questions but with emphasis on the former to facilitate the analysis of the results. The structured interview guide was divided into four sections. The first section was on the socio-economic characteristics of farmers while the second was on the improved practices disseminated and adopted by farmers. The third section attempted to determine the impact of adopted practices on farmers' food productivity. The judgments and opinions of agricultural extension workers who were regarded as experts were used to validate the instrument. The experts selected for this task included

Lecturers in Department of Agricultural Economics and Extension Services.

Experienced extension agents from ADP.

The experts independently judged the instrument based on the objectives of the study and made correction. The reliability of the instrument was obtained from pre-test results collected from 20 farmers outside the sample group, specifically from Jattu and Agenebode in Edo North Agroecological Zone. Using the split-half method, the researcher obtained a reliability coefficient (r) of 0.84 . This result certified the instrument good to be used for the research.

Data collected was analyzed using both descriptive statistics and budgetary tools.

\section{Results}

\subsection{Socio Economic Characteristics of the Respondents}

\subsubsection{Sex}

Farmers' personal and socio-economic characteristics are presented in Tables 2 and 3. More than half (57.7\%) of the respondents were female and the remaining $42 \%$ were male.

\subsubsection{Age}

The age distribution as shown in Table 2 indicates that majority $(60.2 \%)$ of the respondents were above 41 years of age.

\subsubsection{Marital Status}

Table 2 shows that a high proportion $(62.2 \%)$ of the respondents was married while $9.6 \%$ were single. The divorce rate seemed low at $7.1 \%$ but the proportion of respondents that was widowed was significantly high $(21.2 \%)$.

\subsubsection{Educational Qualification}

The level of education of the respondents is shown in Table 2. Majority of the respondents, (56.4\%) had only primary education and about $23.7 \%$ had no formal education. About $13.5 \%$ of the respondents had secondary education while only about $6.4 \%$ had tertiary education. This result shows that a majority of the respondents have a low level of education 


\subsubsection{Number of Dependents}

As shown in Table 2, a significantly high proportion of respondents (69\%) had more than 6 dependents; while only $7.7 \%$ of the respondents had 2 dependents.

\subsubsection{Type of farmer}

As shown in table 3, majority of the respondents (73.7\%) were subsistence farmers while only $26.6 \%$ were commercial farmers.

\subsubsection{Experience in Farming (in Years)}

Only $20 \%$ of the respondents had less than 5 years' experience in farming. The rest had more than 5 years' experience, with $32.4 \%$ having more than 15 years' experience.

\subsubsection{Farm Size (Ha)}

About half of the population (49.4\%) owned farms less than one hectare large, $25 \%$ owned farms 2-3 hectares large, while those that owned farms $4-5$ hectares large were $19.2 \%$. Only $6.4 \%$ of the respondents owned farms more than 5 hectares large.

\subsubsection{Type of Crops Planted}

Majority of the farmers (72.4\%) planted food crops while only $27.6 \%$ planted export crops.

\subsubsection{Holding Type}

Sixty-five percent of the farmers claimed to own the land on which they are farming. However, $21.7 \%$ and $13.3 \%$ rented and leased the land they were using for farming.

\subsubsection{Type of Labor}

The farmers and their families did most of the work in the farms. Only $21.7 \%$ of the labor used by the farmers was hired.

\section{Discussion}

Farmers' personal and socio-economic characteristics are presented in Tables 2 and 3. More than half (57.7\%) of the respondents were female. Sixty percent of the respondents were above 41 years old, while only $6.4 \%$ were less than 21 years and $33.3 \%$ were between $21-40$ years. This result shows the aged nature of most respondents and the need to encourage most young people to take up agriculture as a profession.

Sixty-five percent of the respondents claim to own their farmlands, while $21.7 \%$ and $13.3 \%$ rented and leased land for farming. Majority $(72.4 \%)$ of the respondents planted food crops while only $27.6 \%$ dealt with export crops. About half (49.4\%) of the respondents, owned farms less than one hectare large. The real big timers with farms larger than five hectares constitute only $6.4 \%$ of the farmers. This result shows the subsistence nature of agriculture in Edo State. This is further corroborated by the number of dependents, which shows that most of the farmers $(69.2 \%)$ have more than six dependents. Most of the work in the farms is done by the farmers themselves and their families. Hired labour constitutes only $21.7 \%$. About half $(56.4 \%)$ of the respondents had primary education, while $13.5 \%$ had secondary education. However, $23.7 \%$ had no formal education and only $6.4 \%$ had tertiary education. This result shows that the educational level of the farmers is quite low. This finding is in agreement with that of Fabiyi and Doma (2001) who reported a low level of education among rural women in Dass Local Government Area. Tologbonse and Osanyintade (2001) also reported that the low level of education among the farmers in the Federal Capital Territory, Abuja affected their level of adoption of cowpea crop protection recommendations.

Education places farmers in a position to be receptive to innovative ideas, as it is known to create a positive mental attitude towards adoption of modern farming techniques (1976). Egbugara (1993) noted that the level of a farmers' education is related to the level of innovations he or she adopts. This is also in line with Adams (1982) who proffered that the main way to improve farm efficiency and to increase agricultural production is to educate farmers. Ogunbameru and Pandey (1992) working in Adamawa and Taraba States saw education as a tool for realizing fullest potentials for contribution to agricultural development.

Table 2. Social characteristics of Respondents $(n=156)$

\begin{tabular}{|c|c|c|}
\hline Variable & Frequency & Percentage \\
\hline \multicolumn{3}{|l|}{ Sex } \\
\hline Male & 66 & 42.3 \\
\hline Female & 90 & 57.7 \\
\hline \multicolumn{3}{|l|}{ Age } \\
\hline Less than 21 years & 10 & 6.4 \\
\hline $31-40$ years & 23 & 14.7 \\
\hline $41-50$ years & 37 & 23.7 \\
\hline $51-60$ years & 58 & 37.2 \\
\hline Above 60 years & 28 & 17.9 \\
\hline \multicolumn{3}{|l|}{ Marital status } \\
\hline Married & 97 & 62.2 \\
\hline Single & 15 & 9.6 \\
\hline Divorced & 11 & 7.1 \\
\hline Widowed & 33 & 21.1 \\
\hline \multicolumn{3}{|c|}{ Educational Qualification } \\
\hline No formal education & 37 & 23.7 \\
\hline Primary Education & 88 & 56.4 \\
\hline Secondary Education & 21 & 13.5 \\
\hline Tertiary Education & 10 & 6.4 \\
\hline \multicolumn{3}{|l|}{ Number of dependents } \\
\hline 2 & 12 & 7.7 \\
\hline $3-5$ & 36 & 23.1 \\
\hline $6-8$ & 64 & 41.0 \\
\hline Above 8 & 44 & 28.2 \\
\hline
\end{tabular}


Table 3. Economic characteristics of respondents $(n=156)$

\begin{tabular}{lll}
\hline Variable & Frequency & Percentage \\
\hline Type of farmer & & \\
Subsistence farmer & 115 & 73.7 \\
Commercial farmer & 41 & 26.3 \\
Experience in farming (in years) & & \\
Less than 5 years & 31 & 20.0 \\
6-10 & 27 & 17.3 \\
11-15 & 47 & 30.3 \\
More than 15 years & 51 & 32.4 \\
Farm size (Ha) & & \\
Less than hectare & 77 & 49.4 \\
2-3 & 39 & 25.0 \\
4-5 & 30 & 19.2 \\
Above 5 hectares & 10 & 6.4 \\
Type of crops planted & 34 & 21.7 \\
Food crops & 113 & 72.4 \\
Export crops & 43 & 27.6 \\
Holding type & & \\
Rented & & \\
Leased & & \\
Owned & & \\
Type of labor & & \\
Self-only & & \\
Family labor & & \\
\hline & & \\
Hired labor & & \\
\hline
\end{tabular}

Source: Field survey data $(2 \%)$

\subsection{Effect of T\&V on Farmers Farm Size}

As shown in table 4 , before the commencement of $\mathrm{T} \& \mathrm{~V}$, majority $(63.5 \%)$ of the respondents owned farms less than one hectare in size. Only $2.6 \%$ of the respondents own owned farms larger than five hectares in size. The rest of the respondents owned farms with sizes between one and five hectares.

Table 4 shows that after the commencement of T\&V the percentage of respondents owning farms less than one hectare dropped from $63.5 \%$ to $49.4 \%$. Consequently, the percentage of respondents owning farms 2-3 hectares large increased from $18.6 \%$ - $25 \%$, those owning farms $4-5$ hectares large from $15.4 \%-19.2 \%$ and those owning farms greater than five hectares increased from $2.6 \%-6.4 \%$.

Table 4. Farm sizes of respondents before and after the commencement of $T \& V$

\begin{tabular}{lllll}
\hline Farm size (ha) & Before & \multicolumn{3}{c}{ After } \\
\hline & F & $\%$ & F & $\%$ \\
$<1$ & 99 & 63.5 & 77 & 49.4 \\
$2-3$ & 29 & 18.8 & 39 & 25.0 \\
$4-5$ & 24 & 15.4 & 30 & 19.2 \\
$>5$ & 4 & 2.6 & 10 & 6.4 \\
\hline
\end{tabular}

\subsection{Effect of T\&V on the Incomes of Farmers in The study Areas}

As shown in table 5, majority of the respondents (70.5\%) earn less than 5000 Naira monthly from their farms, while only $29.5 \%$ earn more than 5000 Naira monthly from their farms.

After the commencement of $\mathrm{T} \& \mathrm{~V}$, as shown in table 5, the percentage of respondents who earn less than 5000 Naira monthly dropped from $70.5 \%-54.5 \%$. On the other hand, the percentage of farmers earning more than 5000 Naira monthly from their farms increased from $29.5 \%$ $45.5 \%$. The results show that there was a general increase in income of the farmers after the commencement of T\&V. Logically, usage of improved varieties coupled with best practices in the farms led to increased yield which brought more money to the farmers.

Table 5. Monthly Income of farmers before and after the commencement of $T \& V$ (Naira)

\begin{tabular}{lllll}
\hline Monthly Income & Before & \multicolumn{3}{c}{ After } \\
\hline & F & $\%$ & F & $\%$ \\
$>1000: 00$ & 42 & 26.9 & 15 & 9.6 \\
$1001-5000$ & 68 & 43.6 & 70 & 44.9 \\
$5001-9000$ & 39 & 25.0 & 47 & 30.1 \\
$>9000$ & 7 & 4.5 & 24 & 15.4 \\
\hline
\end{tabular}

\subsection{Respondents' Perceived Benefits from Training and Visit Extension System}

The result in Table 6 shows the respondents' perceived benefits from Training and Visit. The respondent's perceived increased yield at harvest as the first benefit and this was followed by increased income. Other benefits include improved household food security and nutrition, proper use of improved varieties, purchase of articles of convenience, increased access to research information, purchase of more farming equipment, improved housing conditions, improved educational status, increased farm sizes, reduced farm losses, enhanced social status in community, access to credit facilities and more labor employed

The distribution of respondents by their perception of the impact of adopted farming practices on farm productivity before and after adoption of improved practices is shown in table 6. Majority of the farmers had positive perception that the adopted farming practices had increased their income $(84.6 \%)$, increased their yield at harvest (84.0\%), improved their feeding habits/household food security $(83.3 \%)$, and they were able to make use of improved varieties (75.2\%). Many of the respondents had positive perception of increased ability to purchase articles of convenience such as cars and cooking gas $(70.1 \%)$ due to their increased income. They also felt positively that their social status in community had been enhanced (73.1\%). Most of the 
farmers $(82.6 \%)$ had positive perception that they experienced reduced farm losses as a result their adoption of improved farming practices. This finding agrees with Ogunwale et al. (2006) who reported that contact with extension agents and the use of various recommendations had positive impact on the standard of living of farmers as a result of increased income. Majority of the respondents (78.4\%); however, perceived that access to credit facilities had not been improved, which was evident in the negative perception indicated by farmers. This development is worrisome and calls for concern by the authorities concerned.

Table 6. Respondents' perceived benefits from T\&V Extension System

\begin{tabular}{|c|c|c|c|}
\hline T\&V strategy & Mean & Standard deviation & Rank \\
\hline Increased yield at harvest & 2.17 & 1.33 & 1 \\
\hline Increased income & 2.55 & 1.15 & 2 \\
\hline \multicolumn{4}{|l|}{ Improved household food } \\
\hline Security and nutrition & 2.30 & 0.95 & 3 \\
\hline $\begin{array}{l}\text { Purchase of farming } \\
\text { equipment }\end{array}$ & 2.20 & 0.97 & 4 \\
\hline \multicolumn{4}{|l|}{$\begin{array}{l}\text { Increased access to } \\
\text { research }\end{array}$} \\
\hline Information & 2.19 & 0.93 & 5 \\
\hline \multicolumn{4}{|l|}{ Purchase of articles of } \\
\hline Convenience & 2.71 & 0.89 & 6 \\
\hline $\begin{array}{l}\text { Use of improved } \\
\text { varieties }\end{array}$ & 2.16 & 0.85 & 7 \\
\hline Increased farm sizes & 2.15 & 0.98 & 8 \\
\hline $\begin{array}{l}\text { Improved housing } \\
\text { condition }\end{array}$ & 2.12 & 0.99 & 9 \\
\hline $\begin{array}{l}\text { Improved educational } \\
\text { status }\end{array}$ & 2.01 & 1.00 & 10 \\
\hline Reduced farm lose & 2.01 & 1.00 & 11 \\
\hline \multicolumn{4}{|l|}{ Enhanced social status in } \\
\hline Community & 1.81 & 0.97 & 12 \\
\hline More labour employed & 1.68 & 0.91 & 13 \\
\hline $\begin{array}{l}\text { Access to credit } \\
\text { facilitates }\end{array}$ & 1.51 & 0.82 & 14 \\
\hline
\end{tabular}

\section{Conclusion}

The study established the following findings from the study:

1. Women dominated the farming population in the study area and majority of the farmers were above the age of 41 years.

2. The level of education of the respondents was low with majority having only primary education while some had no formal education.

3. Most of the respondents were married with a household size of more than six.

4. Majority of the respondents were subsistence farmers.

5. The findings also showed that respondents generally increased their farm sizes after the commencement of T\&V.

6. There was a general increase in the income of respondents after the commencement of $\mathrm{T} \& \mathrm{~V}$ compared to before. Many of the farmers now earn monthly salaries above the 7500 Naira minimum wage set by the Government for all federal civil servants in Nigeria.

\section{References}

[1] Adams, M. E. (1982), Agricultural Extension in DevelopingCountries, Longman Group Ltd. Singapore, pp 108.

[2] Ada-Okungbowa, C.I. and Ojukoko, O. (2003) "Comparison of Adopters and Non-Adopters of Improved Cassava Varieties in Delta State", J. of Agriculture, Forestry and Fisheries, (3\&4): 15-18.

[3] Adebayo, O.O. and Adeola, R.G. (2005), Socio-economic factors affecting Poultry farmers in Ejigbo Local Government Area of Osun State.Journal of Human Ecology, 18:39-41.

[4] Adekoya, A.E. and Tologbonse E.B. (2005), adoption and diffusion of Innovations. Agricultural Extension in Nigeria. Adedoyin S.F. (ed), pp 28-37.

[5] Agbamu, J. U. (2000). Agricultural Research- Extension Linkage Systems: An International Perspective. Agricultural Research \& Extension (AgREN) Network Paper. No. 106.

[6] Ajayi, M.T. and Okafor, C. (2006): "Extension Agents' perception of Participatory Agricultural Extension Approaches adopted by Agricultural Development Programme (ADP) in Ondo State, Nigeria." International Journal of Agricultural and Biological Sciences, 4(1): 20-25.

[7] Akinbode, I. A. (1976) The Organisation and effectiveness of Extension Services in Nigeria. Agricultural Administration, Applied Science Publishers Ltd. England.

[8] Ali, M. M. and Halim, A. (1985). The effects of T\&V system of Extension at Farmers level in Borga. In GTI publication, Bangladesh Agric University Press, No. 52.

[9] Apantaku, S. O., (2004). Analysis of Senior Secondary Agricultural Science Students' Attitude towards Agricultue as a Career. Journal of Extension Systems Vol. 20(1), June.

[10] Atala, T.K., T. Arokoyo and P.A. Omata, 1992. The impact of the Training and Visit $(\mathrm{T} \& \mathrm{~V})$ System of extension on adoption of farm innovations And farm output in Kaduna State, Nigeria. The Nig. J. Agric. Ext., 7: 59-70.

[11] Benor, .D and Baxter .M (1984) Training and Visit Extension. The World Bank, Washington D. C.

[12] Benor, D. and Harrison, J. Q (1977) Agricultural Extension: The Training and Visit System", the World Bank, Washington D. C.

[13] Blankenburg, P. V. and Hoeper B. (1985) Organisational changes and Persistence: Observations in the introduction of the T\&V system of Extension in two Indian States. Quarterly J. of International Agric. Vol. 24, No. 4, pp 306321 .

[14] Brech, E. F. L. (1983), the Principles and Practices of Management, $3^{\text {rd }}$ edition, London, Longman. 
[15] Cernea, M.M. and Tapping, B. (1977) A system for Monitoring and Evaluating Agricultural Extension Projects. World Bank staff Working Paper No. 277.World Bank, Washington D. C.

[16] Dejene, A. (1985) The T\&V Extension for small Farmers; Lessons in the Design of Extension Programmes for high cereal production Regions in Ethiopia, Development Discussion Papers No. 199, N. Y. University Press, pp 39.

[17] Edo State Agricultural Development Project (2001) Annual Report of Activities, pp 5-10.

[18] Edo State Agricultural Development Project/On Farm Adaptive Research (2002), Annual Report of Activities.

[19] Egbugara, C.A. (1993) Economic Status and Rural women's involvement in Agriculture in Imo State. Journal of Rural Extension and Development. Vol. 1, pp 87-93.

[20] Egharevba, P. N. (1996) Food- The sustainers of life. Inaugural Lecture Series 44, University of Benin, Nigeria. Pp 7.

[21] Ekumankama O.O. and Onuekwusi G.C. (2008). Comparative Analysis of the Constraints to Effective Extension Services in Abia and Akwa Ibom States. Pakistan J. of Soc. Sc. 5(1): 70-75.

[22] Fabiyi, E. F. and Doma U.D. (2001), Status of Rural women's education in Dass Local Government Area and its implication in Agricultural Research, T. A. Olowo (ed), Proceedings of the $7^{\text {th }}$ Annual National Conference of AESON in ARTMI, Ilorin.

[23] Food and Agriculture Organization (FAO 1997)1. Improving Soil fertility in Africa. FAO soils Bulletin 14, Rome.

[24] Feder, G., Slade, R. H. and Sundaram, A. K. (1986). The T\&V Extension System; an analysis of operation and effects Journal of Agric Admin, Vol. 12, No. 1, pp 33-59.

[25] Flippo, E. W. (1965), Principles of Personnel Management. Prentice Hall Inc. Eaglewood Cliffs, New Jersey, U.S.A.

[26] Garforth, C. (1997) Supporting Sustainable Agriculture through Extension in Asia; New resource perspectives, O. D. L. London, No. 21, June, pp 1-5.

[27] Gautam M. (1999). Agricultural Extension, the Kenya Experience. World Bank Agricultural Extension in Kenya. Report No. 19523.

[28] Ilevbaoje, I. E. (2004), Training and Visit Extension System Flourishes in Nigeria. BeraterInnen News 1/2004.

[29] Iloeje, N.P (2002). A New Geography of Nigeria. New Revised Edition, Longman Nigeria Ltd. Pp 155.

[30] Isiaka B.T. (1998). Livestock rearing practices and problems in Lagos. In Oduguwa, O.O., Fanimo, A.O. and Osinwo, O.A., (Eds). Proceedings of the Silver Anniversary Conference, Nigerian Society for Animal Production. Gateway Hotel Abeokuta, pp 223-225.

[31] Jaja, J. S., Chukuigwe, E. C. and Ekine, D. I. (1998) Stimulating Sustainable Agricultural Development through youth mobilisation Schemes: The case of the School-to-land Programme in Rivers State, Nigeria. In Nwosu, A. C. and Mbanassor, J. A. (eds.); Sustainable Agricultural Investment in Nigeria. Proceedings of the $13^{\text {th }}$ Annual Conference of
Farm Management Association of Nigeria. Alphabet Nigeria Publishers, Oweri, pp 294-301.

[32] Jibowo, A.A. (2005): History of Agricultural Extension in Nigeria, in Adedoyin, S.F. (ed.) Agricultural extension in Nigeria, Ilorin Agricultural Society of Nigeria. Pp. 1-12.

[33] La-Anyane, S. A. (1976) Agricultural Research and Extension in National Development in West Africa. Journal of the Association for Advancement of Agricultural Science in Africa. Vol. 3, No. 2,pp 7-12.

[34] Laogun, E. A. (1985) Perception of Farmers' Training Needs: A Case of Isoya Rural Development Project in Oyo State. The Nigerian Journal of Agricultural Extension. Vol. 3, Nos. 1\&2, pp 12-17.

[35] Lawal B.O., Torimiro D.O. and Makanjuola B.A. (2009), Impact of Agricultural Extension Practices on the Nigerian poultry farmers' Standard of living: A percept ional Analysis. Tropical and Subtropical Agro ecosystems, $10: 465-473$

[36] Matata, P. Z., Ajayi O. C., Oduol P.A. and Aggrey Agumya (2008), Socio-Economic factors influencing adoption of improved fallow practices Among smallholder farmers in Western Tanzania. International NGO Journal Vol. 3 (4), pp. 068-073.

[37] Mehta, N. N. (1983), Developing Technical Recommendations and Research - Extension Linkages: Experiences in India. In Michael M. et al (eds.); Agricultural Extension by Training and Visit - The Asian Experience, U. N. D. P. and World Bank, Washington D. C.

[38] Mosher, A. T. (1976) Thinking about Rural Development, ADC Inc. Washington DC.

[39] Munyua, C. N., Adams P. F. And Thomson J. S. (2002) Designing Effective Linkages for Sustainable Agricultural Extension Information SystemAmong Developing Countries in Sub-Saharan Africa. Proceedings of The $18^{\text {th }}$ Annual Conference, Durban, South Africa.

[40] Odebode S.O and Chia H.M. (2001) Poverty alleviation Strategies of rural Household in Mezam Division, Northwest Province, Cameroon.Moore Journal of Agricultural Research. Vol. 2 No 2 pp 179-185.

[41] Odeyinka, S. M., Torimiro, D.O., Oyedele, J.O. and Asaolu, V.O. (2007) Farmers' Awareness and Knowledge of Moringa oleifera In South-western Nigeria. A Percept ional Analysis. Asian Journal of Plant Science. 6:320-325.

[42] Ogunbameru, B. O. and Pandey, I. M. (1992), Nigeria Rural Women's Participation in Agriculture and decision-making: Focus on Adamawa and Taraba States, Nigerian Journal Of Agricultural Extension. Vol. 7 pp 71 - 76.

[43] Ogunfiditimi, T.O. and Ewuola, S.O. (1995): The Synthesis of Corporative Agricultural Extension Systems. Emmi Press Ltd. Ibadan, Nigeria.

[44] Ogunsumi, L. O., (2008).Analysis of extension activities on farmers' Productivity in Southwest, Nigeria. African Journal of Agricultural Research Vol. 3 (6), pp. 469-476.

[45] Ogunwale, A.B., Ayode, A.R. and Ayansina, S.O. (2006). Impact of Extension Service on farmers' production activities in Ogbomoso Agricultural Zone of Oyo State, Nigeria. Journal of Agricultural Extension, 9:150-158. 
[46] Omogbemi, O. (1998): Private Sector Involvement in Extension: The Shell Petroleum Development Company of Nigeria Limited example, Proc. of the fourth Annual Conference of the Agricultural Extension Society of Nigeria, 17-19 June, 1998. Pp. 94-98.

[47] Omokhudu, C.A. (1998), Agencies disseminating agricultural Information To farmers in the Northern Agricultural Zone of Edo State, Nigeria, the Nigerian Rural Sociologist, Vol. 2 pp. 92-98.

[48] Omonona, B.T., Yusuf, S.A., Olatunji, O.B. 2004. Determinants of Adoption of White egg shelled layers by poultry farmers in Ogun State,Nigeria. http://www.cababstractsplus.org/abstracts/Abstracts.aspx

[49] Omoregbee, F. E., (2006). Evaluation of the effect of Extension activities Of the Edo State Agricultural Development Programme (ADP) on small scale farmers, Nigeria. (PhD Thesis), University of Benin, Benin City.

[50] Onazi, O. C (1973) Analysis of the Training Needs of Agricultural Extension Workers in the Northern States of Nigeria. Journal of Rural Economics and Development, Vol. 19, No. 2, pp 133-140.

[51] Opeke, L. K (1976) Agricultural Research and Food Production for Africa. Journal of the Association for Advancement of Agricultural Science in Africa. Vol. 3, No. 2, pp17-22.

[52] Osuntogun, A. and Fabiyi, Y. L. (1980) Training for Agricultural and Rural Development in the ECOWAS. J. of Agric Admin Vol. 8, No. 1, pp 3-13.

[53] Patel, A. U. (1982) an Appraisal of Agricultural Extension as a Strategy forAgricultural Development in Nigeria. In T. A. Olowo (ed.); Workshop on effective transfer of technology to Nigerian Farmers, UNIFE/IITA, Ibadan

[54] Phiri D., Franzel S. Mafongoya P., Jere I., Katanga R. Phiri S. (2003). Who is? Using the new technology? The association of wealth status and gender with the planting of improved tree fallows in Eastern province, Zambia. Agroforestry System.

[55] Pickering, D. C (1983) Agricultural Extension: A tool for Rural Development. In Michael et al (eds.); Agricultural Extension by Training and Visit - The Asian Experience. U. N. D.P. and World Bank, Washington D. C.

[56] Project Coordinating Unit (2000) Minutes of meeting of Agricultural Development Projects, Umuahia, Abia State.

[57] Ray, A. K., Atteri, B. R., Sen, A. C. and Mathur, P. W. (1979) Quantitative and Qualitative Impact of T\&V system in different groups of Farmers. A case study of Hooghly District, West Benghal. Indian J. of Agric Econs. Vol. 36, No. 4, pp 11-12.
[58] Rivera, W.M. \& Cary, J. W (1997). Privatizing Agricultural Extension. In Swanson, B. E., Bentz, R. P., \& Sofranko, A. J. (Eds). Improving Agricultural Extension: A Reference Manual. FAO, Rome, 1997. Pp 203-211.

[59] Rucks, C. (1981) what kind of Extension Worker do we need? In Swanson E. et al (eds.); Training for Agriculture and Rural Development. No. 21, Rome, FAO, pp 81-85.

[60] Sappho, H. (1993) Profile of Rural Poverty in Africa: The State of World Rural Poverty. N. Y. Harvard University Press, pp 39.

[61] Sonii D. (1992). Adoption dynamics incentives and constraints the case of Agroforestry. Paper presented at ICRAF DSO training Course.

[62] Tologbonse, E. B. and Osanyintade, M. (2001) Adoption of Cowpea Crop Protection Recommendations by farmers in the Federal Capital Territory, Abuja. In T. A. Olowo (ed.); Proceedings of the $7^{\text {th }} \backslash$ Annual National Conference of AESON, in ARMTI, Ilorin.

[63] Torimiro, D.O., Alao, J.A. and Fapojuwo, O.E. (1999) Relationship between Socio-economic characteristics of farmers and Adoption of improved agricultural technologies in Ogun State, Nigeria. The Nigerian Rural Sociologist $3: 44-51$.

[64] Van den Ban, A. W. \& Hawkins, H. S. (1996). Agricultural Extension. Second Edition. Cambridge, USA: Blackwell Science Ltd.

[65] Vanlauwe B, Giller K. E. (2006). Popular myths around soil fertility Management in sub- Saharan Africa. Agricultural Ecosystem and Environment, 116:34-46.

[66] Williams, S. K. T. (1978) Rural Development in Nigeria. Obafemi Awolowo University Press Ltd., Ile-Ife.

[67] World Bank (1997). Agricultural Extension and Research: Achievements and Problems in National Systems. World Development Report, 1997. Oxford University press. Oxford.

\section{Biography}

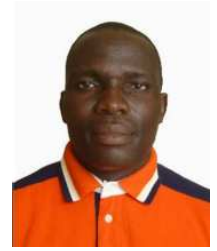

Dr. Abiola Matthew Oladipupo was formerly a Lecturer in Department of Agricultural Economics and Extension Services, University of Benin but $\mathrm{He}$ is currently a Lecturer in Department of Agricultural Economics and Extension, Federal University of Oye,Ekiti State, Nigeria 